\title{
Customer Perception on Service Quality in Retail Banking in Developing Countries - A Case Study
}

\author{
Md. Abdul Muyeed (Associate Professor) \\ Department of Economics, Islamic University, Kushtia 7003, Bangladesh \\ E-mail:mamuyeed@hotmail.co.uk
}

\author{
Received: November 19, $2011 \quad$ Accepted: December 19, $2011 \quad$ Published: February 1, 2012 \\ doi:10.5539/ijms.v4n1p116 URL: http://dx.doi.org/10.5539/ijms.v4n1p116
}

\begin{abstract}
The purpose of this paper is to evaluate the service quality in retail banking in the developing countries in general, and Bangladesh in particular. This is an analytical study based mainly on the primary data collected through scientifically developed questionnaire. The questionnaire has been personally administered on a sample size of 250, chosen from four banks in Bangladesh located in the northern district of Kushtia. The result indicates that customers' perception has reached on highest in the Prompt and accuracy in transactions of the bank and lowest in the service of modern equipment and décor. Due to the increasing competition in retail banking, customer service is an important part and bank must give their due attention to the customers' perception about service quality.
\end{abstract}

Keywords: Service quality, Developing country, Bank, Retail banking, Bangladesh

\section{Introduction}

Commercial banks - assaulted by the pressures of globalization, competition from non-banking financial institutions, and volatile market dynamics - are constantly seeking new ways to add value to their services Because financial services compete in the marketplace with generally undifferentiated products, service quality becomes a primary competitive weapon (Stafford, 1996). Currently technological changes are causing banks to rethink their strategies for services offered to both commercial and individual customers (Hossain and Shirely, 2010). Moreover, banks that excel in quality service can have a distinct marketing edge since improved levels of service quality are related to higher revenues, increased cross-sell ratios, higher customer retention (Bennett and Higgins, 1988), and expanded market share (Bowen and Hedges, 1993). Therefore, banks should focus on service quality as a core competitive strategy (Chaoprasert and Elsey, 2004).

Within this background customer satisfaction and service quality are compelling the attention of all banking institutions around the world and in recent years, academicians and practitioners give more attention in this area as it assumed that service quality is a critical measure of firm performance (Lasser et al., 2000; Yavas and Yasin, 2001; Bick et al. 2004; Andreassen and Olsen, 2008). Therefore, the objective of the paper is to test a service quality instrument by using retail banking services in the developing counting like Bangladesh as a case point.

\section{Concept of service quality}

As mentioned before that Service quality has been wildly used to evaluate the performance of banking services (Cowling and Newman, 1995). Moreover service quality can be defined as the difference between customers' expectations for service performance prior to the service encounter and their perceptions of the service received (Asubonteng et al., 1996). Gefan (2002) also defined service quality as the subjective comparison that customers make between the quality of the service that they want to receive and what they actually get. The banks understand that customers will be loyal if they receive greater value than from competitors (Dawes and Swailes, 1999) and on the other hand, bank can earn high profits if they are able to position themselves better than their competitors within a specific market (Davies et al., 1995). Therefore, banks need focus on service quality as a core competitive strategy (Chaoprasert and Elsey, 2004). Moreover, customers evaluate banks' performance mainly on the basis of their personal contact and interaction (Grönroos, 1990).

Many scholars agree that service quality can be decomposed into two major dimensions (Grönroos, 1983; Lehtinen and Lehtinen, 1982). The first is referred to by Zeithaml et al., 1985 as "outcome quality" and second 
by Grönroos (1984) as "technical quality". However, the first dimension is concerned with what the service delivers and on the other hand, the second dimension is concerned with how the service is delivered: the process that the customer went through to get to the outcome of the service. However, service quality can be also defined as "a judgment about a service's overall excellence or superiority" (Schneider \& White, 2004, p. 51).

\section{Literature review}

The central issues involved in meaning service quality have been well documented (Cronin and Taylor, 1992; Parasuraman, Berry, and Zeithaml, 1991b; Babakus and Boller, 1992; Carman, 1990). Of interest here are two aspects of service quality measurement; (1) the number of dimensions that constitute service quality and (2) the operationalization of the measurement. Previous researchers have been looking at the linear relationship between service quality and satisfaction judgments. In recent studies on satisfaction judgments, it has been suggested that the relationship should be in a non-linear form (Ding, 2004). According to Taylor (1997), there is evidence that suggests that evaluation of satisfaction should involve a curvilinear or higher order form as well as an interaction effect (Taylor and Baker, 1994). This has been confirmed by Oliva et al. (1992) who stated that the satisfaction function should not be in the linear form. A study by Edris (1997) on quality for business customers among Kuwaitis found that local ownership is one of the determinants for bank selection.

On the other hand, a study by Athanassopoulus (1997) showed that there is no global difference between private and the government-owned banks. There are many other researchers who concluded that service quality is the antecedent to satisfaction (Ahmad and Kamal, 2002; Cronin and Taylor, 1992; Yavas et al., 1997). Hence in this research, the question of which one is the antecedent will be studied. Using service quality as the antecedent to satisfaction is more logical and that why it has been taken into consideration. This is because satisfaction is an important goal to be achieved by bank marketers and if the banks want to increase satisfaction, they can do it through service quality (Goode et al., 1996).

\section{Economic environment of Bangladesh}

Bangladesh is situated at the unique juxtaposition of the composite, sprawling, interlinked Ganges-Brahmaputra-Meghna (GMB) river systems, the second largest river system in the world, which drains an area of 1,086,000 square kilometers from China, Nepal, India and Bangladesh (USAID, 2011).

The population of Bangladesh is 142.3 million (census 2011 results) and it is the 8th most populous nation in the world. In 1951, the population was 44 million. It is also the most densely populated large country in the world, and it ranks 11th in population density, when very small countries and city-states are included (http://en.wikipedia.org/wiki/Bangladesh).

Because of this unique geophysical location, the country has been endowed with rich biological diversity, hosting a rich variety of species superbly evolved to populate the ecosystems of the country. However, due to the various pressures of a growing population (with an already existing base of 145 million people), development interventions, gaps in policy and legislation, and conflicting institutional mandates, $95 \%$ of Bangladesh's natural forests and 50\% of its freshwater wetlands are lost or degraded (USAID, 2011).

The economy has grown 5-6\% per year since 1996 despite political instability, poor infrastructure, corruption, insufficient power supplies, and slow implementation of economic reforms. Although more than half of GDP is generated through the service sector, $45 \%$ of Bangladeshis are employed in the agriculture sector, with rice as the single-most-important product. Bangladesh's growth was resilient during the 2008-09 global financial crisis and recession. Garment exports, totaling $\$ 12.3$ billion in FY09 and remittances from overseas Bangladeshis totaling $\$ 9.7$ billion in FY09 accounted for almost 25\% of GDP (CIA World Fact Book, 2011).

Financial market in Bangladesh essentially consists of banks and non-bank financial institutions and capital market which include state owned commercial banks (SCBs), private commercial banks (PCBs), foreign commercial banks (FCBs), government owned specialized banks, non-banking financial institutions (NFIs), Investment Corporation of Bangladesh (ICB), House Building Finance Corporation 59 (HBFC), Dhaka Stock Exchange (DSE), and Chittagong Stock Exchange (CSE). Besides, a total of 44 general insurance companies (1 state-owned) and 18 life insurance companies (1 state-owned) are operating in the country (www.mof.gov.bd/en/.../11.../Chapter-5\%20\%20_Eng-2010_.pdf)

As of June, 201047 scheduled banks which include 4 state-owned commercial banks, 30 private commercial banks, 9 foreign-owned commercial banks, 4 government-owned specialized banks, are operating in Bangladesh through their 7,246 branches. Among those branches as many as 3,394 belong to state-owned commercial banks, 2,427 branches to local private banks, 59 branches to foreign banks and 1,366 branches to specialized banks. Moreover, there are 1 National Co-operative Bank, 1 Ansar VDP Bank, 1 Karmasangsthan Bank and 1 Grameen 
Bank which are operating as the non-scheduled banks. In Bangladesh, 4,169 branches of the scheduled banks are operating in the rural area (www.mof.gov.bd/en/.../11.../Chapter-5\%20\%20_Eng-2010_.pdf).

Bangladesh Bank has been working as the central bank since the country's independence. Its prime jobs include issuing of currency, maintaining foreign exchange reserve and providing transaction facilities of all public monetary matters. To comply with international best practices and to make the bank's capital more resilient as well as to build the banking industry more risk sensitive, shock absorbent and stable, Bangladesh Bank commenced implementation of Basel-II capital adequacy framework from January 2010 as regulatory requirement for banks (www.mof.gov.bd/en/.../11.../Chapter-5\%20\%20_Eng-2010_.pdf).

\section{Methodology}

This is a study based mainly on the primary data collected through scientifically developed questionnaire. The questionnaire has been personally administered on a sample size of 250, chosen from four banks, two from public sector and two from private sector, i.e Sonali Bank, Janata Bank (public banks) Arab Bangladesh Bank Ltd and National Bank Ltd. (private banks).

The questionnaire has been designed on the basis of the study of scholars such as Parasuraman et al. (1985), Hossain and Shirely (2010). Parasuraman et al. (1985) and Hossain and Shirely (2010) identified eleven dimensions of service quality which are reliability, responsiveness, competence, access, courtesy, communication, credibility, security, competence, understanding the customer and tangibles. Upon considering the above studies, we have constructed four dimensions (reliability, competence, tangibles and empathy) which cover the 14 parameters/scale (Table 1). The degree of perception of customers on the parameters is quantified by using a 5-point Likert scale. However, customer demographic information was included in the questionnaire.

\section{Findings}

\subsection{Demographic profile of respondents}

The questionnaire was design to seek information about the user groups' age, gender, education, and their occupation. Analysis shows that 80 per cent of the respondents are male and 20 per cent are female. The details breakdown of the demographic profile of the customers has been given in Table 2. It is known from Table 2 that $60 \%$ of the respondents are in the age group of 35 to 45 years. The next largest group of the respondents is in the age group of 25 to 35 years $(25 \%)$. About $10 \%$ respondents are from the age group of below 25 years and only $5 \%$ respondents are in the age group of 45 and above. Analysis also shows that more than half of the respondents are Bachelor degree holders $(60 \%)$, however, Masters holders are $10 \%$ of the total respondents followed by college degree $30 \%$. Among the 250 respondents, the highest numbers of the respondents are in occupation of service sector $(68 \%)$ followed by others $(5 \%)$.

\subsection{Discussion on descriptive statistics of customers' perception}

The following is the discussions on each of the parameters of the customers' perception on service quality of banks.

Customer support: It is an important service that bank used to provide to the customers. Because proper support to the customer may lead to the banks to generate profit and build customers' confidence. The mean score of this parameter is 3.45 with standard deviation of .74 with $\mathrm{Z}$ score 0.99 . The result indicates that customers' perception is positive regarding service provided by the bank in the way of customer support. However, in terms of ranking in the mean score, it stands in the position of 8th (Table 3). This is the indication of poor support provided by the bank to the customer. So, bank should pay more attention to this parameter so that perceptions of customers' get high priority. Good manners and hospitality: It is one of the parts of reliability of service quality that attracts customers of the banks' personnel manner and hospitality. This parameter is not also satisfactory as the mean and $\mathrm{Z}$ score is 3.25 and 0.025 respectively and holding the ranking of 13 th. Therefore, banks need to improve their personnel's manner to great extent. Maintaining of customers grievances: This is an important service quality factor expected by the customer to the bank is to maintain grievances. The mean score and ranked of this parameter is 3.29 and 12 th respectively. The standard deviation 0.86 and $Z$ value is 0 (not exceeding the standard Z score table value of 1.96). It seems that customers' perception in this case is very unsatisfactory and bank should give attention to this issue. Imposing of service charges and fines: Banks has to charge various amounts to the customers' account for their services such as demand draft, money transfer, cheque book issue etc. With regard to this parameter, the mean score is the lowest (2.33) among the 14 parameters. The result indicates that the customers' perception in this case is very unsatisfactory. In other words, banks are imposing service charges and fines too much for which customers dissatisfaction are reflected in the result and bank should minimize the service charges. Prompt and accuracy in transactions: In the banking transaction, customers 
seek to prompt service and accuracy of in transactions. The mean score is 4.02 and the position is ranked at 1 st. It is understand that customers' perception in this case better than customer support, good manner and hospitality, maintaining of customer grievances and imposing of service charge. Safety of customers' investment: The service quality is also depending on how safe is customers' investment. The mean score (3.92) and rank (2nd) of this parameter does indicate that customers are satisfied as other parameters. Keep confidentiality of account and transaction: This is an important parameter and customers want their account and transaction to be kept confidential. The mean score is 3.77 and ranked 4th with standard deviation is almost 0.90 . The result indicates that customers have moderate confidence in this service. Reputation of the bank: Every bank wants to run their business with good reputation. In this case, customers perception is good as mean score is 3.82 and ranked 3rd with standard deviation of 0.89. Infrastructure facilities like parking, ATM etc: There are some preconditions in order to run business like financial institutions, have to provide infrastructural facilities to the customers. The perceptions of the customer in this are moderate (3.56) and ranked 6th. It does mean banks are providing such facilities to the. Banking Network: It is another important aspect of service quality of banking companies. In this case, customer perception is good as mean score is 3.35 and ranked 10th. Modern equipment and décor: In the modern age, business premise should have high standard of decoration of the bank and nice environment. The mean score (3.15) and rank (14th) does not imply that customers' perception is high than other parameters like goodwill, banks network etc. Easy to operating account: It is one of the issue that customers' can operate their account smoothly. The perception of the customers to this service is not good as its mean score is 3.37 and standard deviation is 0.82 . Convenience business hour: Banks are operating their business within a time framework as well as they have to provide extra timing for which customers can do business in comfortable time. For example, some banks offers banking hour at evening. The study revealed that the perception in this case is not satisfactory compared to other services offered by banks. The mean score is (3.48) and ranked (7th) support this statement. Providing prompt information to customers: Bank services like prompt communicating to the customer is vital. Customers are dealing the business transaction with safely and confidently with the banks. In this case, if the banks provide right information to the right customers promptly which create public confidence, and thus help customers to take right decision in right time. In this case, the mean score is 3.64 and ranked 5th which is understand as moderate service proving by the banks.

\section{Conclusion}

As per this study, both public sector and private sector banks appear to be providing services to the satisfaction of customers. The study indicates that customers' perception vary according to the nature of service. Measuring customer satisfaction with surveys or focus groups gives direction to the banks for efforts and valuable inputs for improvement. In this case, the highest customers' perceptions reach in Prompt and accuracy in transactions followed by Safety of customers' investments and keep confidentiality of account and transactions. The banks need to consider the weak areas in order to meet customer requirement. The study has limitations in terms of sample size and if more respondents could be included might be changed in terms of satisfaction ranking.

\section{References}

Ahmad, J., and Kamal, N. (2002). Customer satisfaction and retail banking: an assessment of some of the key antecedents of customer satisfaction in retail banking. International Journal of Bank Marketing, Vol. 20, No. 4/5, pp. 146-61.

Andreassen, T.W., and Olsen, L.L. (2008). The impact of customers' perception of varying degrees of customer service on commitment and perceived relative attractiveness. Managing Service Quality, Vol. 18, No. 4, pp. 309-28. http://dx.doi.org/10.1108/09604520810885581

Athanassopoulus, A.D. (1997). Another look into the agenda of customer satisfaction: focusing on service providers' own and perceived viewpoints. International Journal of Bank Marketing, Vol. 15, No. 7, pp. 264-78.

Babakus, E., \& Boller, G.W. (1992). An empirical assessment of the SERVQUAL scale. Journal of Business Research, 24, 253-268. http://dx.doi.org/10.1016/0148-2963(92)90022-4

Bennett, D., and Higgins, M. (1993). Quality means more than smiles. ABA Banking Journal, June, 46.

Bick, G., Brown, A., and Abratt, R. (2004). Customer perceptions of the value delivered by retail banks in South Africa. The International Journal of Bank Marketing, Vol. 22, No. 4/5, pp. 300-18. http://dx.doi.org/10.1108/02652320410549638

Berry, L.L., Parasuraman, A., and Zeithaml, V.A. (1994). Improved service quality in America: Lessons learned. Academy of Management Executive, Vol. 8, No. 2, pp. 32-52. http://dx.doi.org/10.5465/AME.1994.9503101072 
Bowen, J.W., and Hedges, R.B. (1993). Increasing service quality in retail banking. Journal of Retail Banking, Vol. 15, pp. 21-8.

Carman, J.M. (1990). Consumer perceptions of service quality: An assessment of the SERVQUAL dimensions. Journal of Retailing, 66(1), 33-55.

Chaoprasert, C., and Elsey, B. (2004). Service quality improvement in Thai retail banking and its management implications. ABAC Journal, Vol. 24, No. 1, pp. 47-66.

Cowling, A., and Newman, K. (1995). Banking on People. Personnel Review, Vol. 24, issue 7, pp. 25-41. http://dx.doi.org/10.1108/00483489510095789

Cronin, J.J., and Taylor, S.A. (1992). Measuring service quality: a reexamination and extension. Journal of Marketing, Vol. 56, No. 3, pp. 55-68. http://dx.doi.org/10.2307/1252296

Davies, F., Moutinho, L., and Curry, B. (1995). Construction and testing of a knowledge-based system in retail bank marketing. International Journal of Bank Marketing, Vol. 13, No. 2, pp. 4-14. http://dx.doi.org/10.1108/02652329510078613

Dawes, J., and Swailes, S. (1999). Retention sans frontiers: issues for financial service retailers. International Journal of Bank Marketing, Vol. 17, No.1, pp. 36-43. http://dx.doi.org/10.1108/02652329910254037

Ding Hooi Ting (2004). Service quality and satisfaction perceptions: curvilinear and interaction effect. International Journal of Bank Marketing, Vol. 22, Iss: 6, pp.407 - 420 . http://dx.doi.org/10.1108/02652320410559330

Edris, T.A. (1997). Services considered important to business customers and determinants of bank selection in Kuwait: a segmentation analysis. International Journal of Bank Marketing, Vol. 15, No. 4, pp. 126-33. http://dx.doi.org/10.1108/02652320410559330

Gefen, D. (2002). E-commerce: the role of familiarity and trust. International Journal of Management Science, Vol. 8, No. 6, pp. 725-37.

Goode, M.M.H., Moutinho, L.A., and Chien, C. (1996). Structural equation modeling of overallsatisfaction and full use of services for ATMs. International Journal of Bank Marketing, Vol. 7, pp. 4-11. http://dx.doi.org/10.1108/02652329610151331

Grönroos, C. (1984). A Service Quality Model and Its Marketing Implications. European Journal of Marketing. 18(4), pp. 36-44. http://dx.doi.org/10.1108/EUM0000000004784

Grönroos, C. (1990). Service management and marketing. Lexington Books, Lexington, MA.

Hossain, M., and Sherloy, L. (2010). Customer Perception on Service Quality in Retail Banking in Middle East: the Case of Qatar. International Journal of Islamic and Middle Eastern Finance and Management, Vol. Volume, 2, No. 4, pp. 338-350. (ISSN: 1753-8394).

Lasser, W.M., Manolis, C., and Winsor, R.D. (2000). Service quality perspectives and satisfaction in private banking. Journal of Services Marketing, Vol. 14, No. 3, pp. 244-71. http://dx.doi.org/10.1108/08876040010327248

Lehtinen, U., and Lehtinen, J.R. (1982). Service quality: a study of quality dimensions. Working Paper. Service Management Institute. Helsinki.

Oliva, T.A., Oliver, R.L., and MacMillan, I.C. (1992). A catastrophe model for developing service satisfaction strategies. Journal of Marketing, Vol. 56, No. 3, pp. 83-95. http://dx.doi.org/10.2307/1252298

Parasuraman, A., V. Zeithaml and Berry, L. (1985). A Conceptual Model of Service Quality and Implications for Future Research. Journal of Marketing, 49(4), pp. 41-50. http://dx.doi.org/10.2307/1251430

Parasuraman, Berry and Zeithaml. Refinement and Reassessment of the SERVQUAL Scale. Journal of Retailing, Winter 1991, pp. 420-50.

Schneider, B., and White, S. (2004). Service Quality Research Perspectives. Sage, Thousand Oaks, CA.

Stafford, M.R. (1996). Demographic discriminators of service quality in the banking industry. The Journal of Services Marketing, Vol. 10, No. 4, pp. 6-22. http://dx.doi.org/10.1108/08876049610124554

Taylor, S.A. (1997). Assessing regression-based importance weights for quality perceptions and satisfaction judgements in the presence of higher order and/or interaction effects. Journal of Retailing, Vol. 73, No. 1, pp. 135-59. http://dx.doi.org/10.1016/S0022-4359(97)90018-X 
Taylor, S.A., and Baker, T.L. (1994). An assessment of the relationship between service quality and customer satisfaction in the formation of consumers' purchase intentions. Journal of Retailing, Vol. 70, No. 2, pp. 163-78. http://dx.doi.org/10.1016/0022-4359(94)90013-2

Yavas, U., and Yasin, M.M. (2001). Enhancing organizational performance in banks: a systematic approach. Journal of Services Marketing, Vol. 6, pp. 444-53. http://dx.doi.org/10.1108/EUM0000000006099

Yavas, U., Bilgin, Z., and Shemwell, D.J. (1997). Service quality in the banking sector in an emerging economy: a consumer survey. International Journal of Bank Marketing, Vol. 15, No. 6, pp. 217-23. http://dx.doi.org/10.1108/02652329710184442

Zeithaml, V.A., Parasuraman, A., and Berry, L.L. (1985). Problems and strategies in services marketing. Journal of Marketing, Vol. 49, pp. 33-46. http://dx.doi.org/10.2307/1251563

Table 1. List of 14-item service quality included in questionnaire

\begin{tabular}{|l|l|}
\hline Service quality dimensions & 14-item scale/parameters \\
\hline Reliability & $\begin{array}{l}\text { 1. Customer support } \\
\text { 2. Good manners and hospitality } \\
\text { 3. Maintaining of customer grievances } \\
\text { 4. Imposing of service charge }\end{array}$ \\
\hline Competence & $\begin{array}{l}\text { 5. Safety of customers' investment } \\
\text { 6. keep confidentiality of account and transactions } \\
\text { 7. Various kinds of service offered } \\
\text { 8. Reputation of the bank }\end{array}$ \\
\hline Tangibles & $\begin{array}{l}\text { 9. Infrastructure facilities like parking, ATM etc } \\
\text { 10. Banking Network } \\
\text { 11. Modern equipment and décor }\end{array}$ \\
\hline Empathy & $\begin{array}{l}\text { 12. Easy to operating account } \\
\text { 13. Convenience business hour } \\
\text { 14. Providing prompt information to customers }\end{array}$ \\
\hline
\end{tabular}

Table 2. Demographic profile of the customers

\begin{tabular}{|c|c|c|c|c|c|c|c|}
\hline Demographics & $\%$ & Demographics & $\%$ & Demographics & $\%$ & Demographics & $\%$ \\
\hline 1. Gender: & & 2. Age: & & 3. Education: & & 4. Occupation: & \\
Male: 200 & $80 \%$ & Below $25 \mathrm{yrs}$ & $10 \%$ & College level & $30 \%$ & Service 50 & $68 \%$ \\
Female: 50 & $20 \%$ & $25-35$ yrs & $25 \%$ & Bachelor & $60 \%$ & Students 30 & $5 \%$ \\
& & $35-45$ yrs & $60 \%$ & Masters & $10 \%$ & Accountant 20 & $12 \%$ \\
& & 45 above & $5 \%$ & & & Academicians 06 & $5 \%$ \\
& & & & & & Others 14 & $10 \%$ \\
\hline
\end{tabular}


Table 3. Descriptive statistics of customer perception responses

\begin{tabular}{|l|l|c|c|c|}
\hline No. & Parameters & Mean & Std Dev & 'Z' test \\
\hline 1 & Modern equipment and décore & $3.15[14]$ & .9911 & 8.1813 \\
\hline 2 & Good manners and hospitality & $3.25[13]$ & .7085 & 0.0255 \\
\hline 3 & Maintaining of customer grievances & $3.29[12]$ & .8665 & 0.000 \\
\hline 4 & Imposing of service charge & $2.33[11]$ & .3358 & 0 \\
\hline 5 & Infrastructure facilities like parking, ATM etc. & $3.56[6]$ & .8193 & 0.8135 \\
\hline 6 & Convenience business hour & $3.48[7]$ & .7507 & 0.7750 \\
\hline 7 & Keep confidentiality of account and transactions & $3.77[4]$ & .9011 & 0.9913 \\
\hline 8 & Reputation of the bank & $3.82[3]$ & .8929 & 0.998 \\
\hline 9 & Prompt and accuracy in transactions & $4.02[1]$ & .9117 & 0.999 \\
\hline 10 & Customer support & $3.45[8]$ & .7427 & 0.775 \\
\hline 11 & Easy to operating account & $3.37[9]$ & .8213 & 0.371 \\
\hline 12 & Safety of customers' investments & $3.98[2]$ & .8449 & 0.999 \\
\hline 13 & Providing prompt information to customers & $3.64[5]$ & .8811 & 0.975 \\
\hline 14 & Banking Network & $3.35[10]$ & .7705 & 0.874 \\
\hline
\end{tabular}

Note: [ ] indicates the rank of mean score 